\title{
An International Experience Mandate for Undergraduates in a College of Health and Human Services: Initial Assessment
}

\author{
Donna M. Daly ${ }^{1}$, Suzanne Baker ${ }^{1} \&$ Stephen J. Williams ${ }^{1}$ \\ ${ }^{1}$ College of Health \& Human Services Dean's Office, San Diego State University, San Diego, Ca., USA \\ Correspondence: Donna M. Daly, College of Health \& Human Services, San Diego State University, 5500 \\ Campanile Drive, San Diego, Ca, 92182-4124, USA. Tel: 1-619-594-6151. E-mail: ddaly@mail.sdsu.edu
}

Received: October 9, 2012

Accepted: October 29, 2012

Online Published: January 9, 2013

doi:10.5539/jel.v2n1p44

URL: http://dx.doi.org/10.5539/jel.v2n1p44

\begin{abstract}
Educators and student affairs professionals are responding to the call for internationalizing education to keep pace with social, political, and economic globalization. This article provides a qualitative description of the transformation and globalization of an undergraduate college. Successful implementation of a college-wide international initiative is derived from the congruence between an academic agenda, student personal goals, and an institutional priority of globalization. Ultimately, an international experience benefits students academically and in personal growth and maturity.
\end{abstract}

Keywords: study abroad, internationalization of higher education, internationalization of the curriculum, globalization of international higher education

\section{Introduction}

The global nature of our society and of economic, social, and cultural forces is now widely recognized throughout the educational world. Undergraduate education has increasingly sought to incorporate a global perspective into the curriculums of many disciplines and into the nature of general education and learning itself, contributing to the total college experience (Dutschke, 2009; Gacel-Avila, 2005; Green \& Olson, 2003).

This article provides a qualitative description of the transformation and globalization of an entire undergraduate college dedicated to the health and human services professions. It further illustrates the college's commitment to international awareness and sensitivity through a broad mandated graduation requirement applied to all students who matriculated beginning in fall 2010. The empirical conclusions from assessing and formulating the requirement have serious implications for other large educational units seeking to assure a comprehensive global perspective in knowledge and awareness among all students, especially in those fields outside of the traditionally internationally focused majors of study. An experience such as this transcends the academic experience to provide an opportunity for growth and maturity.

Following a description of the college and university, planning evaluation data derived from the development and implementation of a college-wide course that features an international travel component is presented. The discussion concludes with principle considerations in designing and implementing a college-wide international mandate and a graphic that depicts the synergy resulting from the alignment of an academic agenda, student personal goals, and an institutional goal of globalization.

\section{College of Health and Human Services}

The College of Health and Human Services (CHHS) at San Diego State University (SDSU) functions as the "health sciences center" for the university, encompassing most of the applied functional fields related to health care and social services education, training, and research. These include the following schools: Social Work; Public Health, itself encompassing epidemiology and biostatistics, health behavior, health care management, and environmental health; Nursing; Speech, Language, and Hearing Sciences; and Exercise and Nutritional Sciences, including physical therapy. All appropriate programs are professionally accredited. The CHHS was established in the late 1970s to consolidate and highlight the missions of these health and human services fields, to provide a platform for interaction among faculty in related disciplines, and to promote the visibility of the university's commitment to the health and social service fields in the community and nationally.

The current composition of the CHHS includes approximately 4,000 undergraduate and 900 graduate students, 
$62 \%$ from underrepresented populations and $80 \%$ female. The college offers seven undergraduate majors which include: 1) public health; 2) nursing; 3) social work; 4) speech, language, and hearing sciences; 5) gerontology; 6 ) kinesiology, and; 7) foods and nutritional sciences. Master's level programs are offered by each school as are five doctoral programs, offered jointly with the University of California San Diego. The college added a stand-alone doctoral program in Physical Therapy in fall 2012.

The CHHS organizational structure includes an Assistant Dean for Student Affairs who holds a split appointment between Academic Affairs and Student Affairs and serves as a "liaison" between both entities on campus. The college has a full time International Coordinator with a graduate degree in Post-Secondary Educational Leadership with an emphasis in Student Affairs. Both positions focus on the college's international mandate and feature staff with strong student affairs experience. Both have been heavily involved in the international requirement reflecting that this part of the student's education goes beyond the academic component.

In addition to the educational programs, a primary mission of the university and the CHHS is a strong commitment to research, which parallels the university's goal of attracting research oriented faculty and extramural funding. SDSU is a Carnegie Research University: high research activity institution. For the fiscal year 2011-2012, the CHHS recorded approximately $\$ 42.6$ million in external funding, the highest of any college in the university, primarily for applied research and professional training programs. Based on the full-time equivalent faculty tenure track count, this equates to about $\$ 507,000$ per person, the highest average for any college at the university, nearly twice the next college in descending order, Sciences, the highest unit average in the statewide public university system, and among the highest in the nation, certainly comparable to most major research universities. Some of this funding is attributable to specialized faculty research related to border and minority health issues, consistent with the university's physical location and community focus.

\subsection{Global Reach}

The CHHS has other substantial global components. Virtually all of its schools have faculty with expertise in international matters. The Graduate School of Public Health houses the Global Health $\mathrm{PhD}$ program, which is jointly offered with another local large university. The CHHS research agenda includes many global efforts. Many of the units have international education aspects to their graduate programs. For example, the Graduate School of Public Health offers a joint MPH/MA program with Latin American Studies. The School of Social Work offers international opportunities in the MSW program. Many individual graduate courses have an international component and some involve foreign travel. The college also features annual lectures on global health and human services topics such as health care disparities, global health, AIDS and orphans, and rebuilding Haiti's health care system. The CHHS Student Council, the student governing body for the college, has endorsed a global agenda, participates in international philanthropic efforts each year, and hosts an annual "global unity" event.

\section{The University Context}

SDSU is the sixth largest public university in the state, and the fourth largest in the statewide university system, the largest system of higher education by enrollment in the nation. The formal mission statement of the university is a typical combination of education, research, and service. But, more notably for the present discussion, SDSU's academic vision and goal statements include reference to internationalization of programs. Specifically referenced is an expansion of all learning experiences within the university including academic exchanges, curriculum, research, and other scholarly and creative endeavors. The statewide university system and the university also have strong commitments to student services.

SDSU offers 335 international education programs in 52 countries. Nearly 12,000 students have studied abroad in the past 12 years. The university also ranks twentieth in the nation for racial diversity and is among the top universities for economic diversity with a strong commitment to ensuring a diverse student body. The university is sixth in the nation and second in the state for bachelor's degrees awarded to Hispanics and is a designated Hispanic-Serving Institution by the U.S. Department of Education. The university also partners with the Diversity Network to increase diversity among the ranks of students who study abroad.

The international goals have been operationalized over the past fifteen years under the visionary leadership of the university's former and current presidents, provost, and college dean. As a result, SDSU ranks very high nationally in the numbers of students obtaining some international education, and is recognized for promoting international activities. According to the 2011 Institute for International Education's Open Doors Report, the university ranked $22^{\text {nd }}$ in the nation and third in the state for the number of students studying abroad (Institute for International Education, 2011). In 2009-10, the academic year for which the ranking was based, 1,835 university students studied outside the U.S. 
In addition to specific majors that require an international education component (e.g., International Business), there are numerous faculty led international programs, research projects throughout the world, and other elements to operationalize the internationalization goal. Further, specific funds are allocated to support faculty travel for purposes of developing cooperative programs. In 2008 the student body voted to impose a new student fee each semester, which is used to grant student travel awards in support of international study. SDSU has an assistant vice-president leadership position for international programs, with additional support staffing, an extensive international student center assisting incoming and outgoing students, and a very large and well known language training program for non-English speaking students. The university does not have any owned educational facilities abroad.

\section{Experiential Learning: Bridge across Academic and Student Affairs}

Student development theory served as the foundation for the CHHS international requirement. In developing the international experience, the requirement designers took a holistic approach to learning that focused on the quality and quantity of student involvement to enhance student learning outcomes and development (Astin, 1984; Kolb, 1984). This approach is supported by a number of researchers in the student affairs arena. Chickering \& Reisser (1993) outline seven pathways toward the process of individuation. One of the pathways, identity formation, includes exploring social, historical and cultural perspectives to create a sense of self (Chickering \& Reisser, 1993). King \& Baxter Magolda (2005) developed a model of "intercultural maturity" that melds three critical elements of student development (cognitive, intrapersonal and interpersonal). The CHHS requirement adds an "experiential learning component" to classroom discussions and assignments to contribute to a more holistic educational experience which also includes an international experience.

\section{The Undergraduate International Experience Mandate}

To support the mission of the university and to provide students with a global perspective in recognition of the changing world in which they will function professionally, the CHHS instituted a college-wide requirement for international education. This requirement applies to all undergraduate students within the college. This mandate can be met by participating in any approved academic program of study in an international setting requiring at least two weeks of international travel and associated with some form of academic credit. Participation in an SDSU program is not required and qualified external vendor programs may be acceptable. Although an experience in a setting involving health and human services is desirable, that is not required either. An experience in a developing country, while generally desirable to broaden a student's perspective, is not required. For example, health care management faculty has been investigating the development of academic programs involving visiting health care resources in the United Kingdom and in South Korea.

While the specific attributes of the requirement are broadly defined, CHHS students, given their interest in the health professions, are especially attracted to the service learning component of study abroad. A few researchers have examined the effects of participating in international service learning activities (Boyle, et al., 1999; Bringle, et al., 2011; Dyjack, et al., 2001; and Evanson \& Zust, 2004). Participants showed gains in the following areas: cultural awareness; understanding of social justice issues; motivation to pursue future service activities; and enhanced clarity vis-à-vis career path. All of the studies underscore the importance of student involvement in the process, flexible and involved faculty, and the use of curriculum that ties classroom learning to the field.

The international requirement was developed over an approximate three-year time frame by the college's senior leadership. Initially conceptualized to broaden student exposure to other cultures and environments in an increasingly international world, considerable time was spent defining the nature of the requirement in the context of university priorities, general education principles, student services and support requirements, and the nature of the college's majors.

\subsection{Applied International Health and Human Services}

To further assure the availability of multiple opportunities for students, the college now offers a unique course to all undergraduates across the college, and open university-wide. Applied International Health and Human Services (HHS 350) is a survey course regarding health and human services issues in developing countries. The course includes a travel component, broken into sections for various countries, which has recently included travel to Mexico, China, Costa Rica, Switzerland, Thailand, or India. The course meets the university's upper division general education "Explorations" requirement in the area of Social and Behavioral Sciences, as well as the state's Title V Cultural Diversity experience requirement, and the CHHS international study requirement.

This course includes extensive in-class didactic instruction on such topics as demographic trends, health and disease patterns in developing countries, water and air quality, social service needs, adverse treatment of women 
in certain societies, and many other issues of global health and human services. The in-country experiences focus on local population needs, health and human services resources, local political and practical challenges, and other practical concerns. Although there are multiple other study abroad opportunities in the university and elsewhere, this course provides assured capacity for the substantial numbers of students needing to meet the requirement and allows content and delivery control as well.

\subsection{Implementation of the Requirement and Course}

The evolution of HHS 350 has provided a learning laboratory for the architects of the international requirement. Through a combination of trial and error, feedback loops from students, participating faculty and student affairs professionals, site location leaders, and careful analysis, the course and its individual international components were carefully refined over about three years. This iterative process allowed for the opportunity to analyze the processes and outcomes of the effort, and to draw definitive conclusions and recommendations for content, process evaluation methods and criteria, and other key educational elements. The goal was to refine and sharpen the experience, and to further understand the impact of the international requirement on student learning and maturity.

To prepare for the college-wide requirement and course, the CHHS team conducted a literature review, revealing the dearth of research on the planning aspects of education abroad programs. The limited research that is available focuses on two approaches: opportunistic and strategic planning (Edwards, 2007). These two processes generally proceed simultaneously in American institutions; however, faculty support opportunistic planning efforts. The president of Yale University engaged faculty in an institutional planning process to "internationalize" the entire system, an activity driven by strategic targets and the university mission (Edwards, 2007). More recently, McCabe (2011) encourages educators to ponder the mission and value of international study vis-à-vis the larger process of globalization. The importance of placing the CHHS requirement in a valid learning context and in the framework of institutional priorities is especially critical in selling it to students and faculty.

\subsection{University Support}

The university's vision and goal statements support the implementation of a college-wide international study mandate. Campus officials have sought and rewarded leadership leading to internationalization of campus programs. The university's Office of International Programs serves as an information clearinghouse for international projects, funding opportunities, and academic programs and services that have an international component. The office also supports the university-wide goal of "creating a global campus" by promoting internationalization in everything from curriculum content to campus cultural activities and speakers. The CHHS endorses both opportunistic and strategic planning and is aligned with the President's office goal of campus globalization.

SDSU's vision of being a global campus clearly drove decision-making in the college. Those top-down decisions are viewed below in the context of the bottom-up perspective of the student/customer and the value added to their educational programs. Student preferences including logistics and learning opportunities, the integration of service learning into the curriculum, perhaps the most essential aspect of adding this requirement, and creating an appealing setting and experience are the focus of the remaining discussion.

\section{Practical Assessment of Components of the Requirement}

Four years of longitudinal experience with offering an international course specifically targeted to the requirement, and two years of experience with the requirement itself, informs a useful perspective on successfully integrating international study in health and social sciences undergraduate curricula. After each travel experience, students respond to a survey that gauges their satisfaction while participating in international activities. The survey goal is to obtain data that is used to enhance future delivery of the course and improve travel components. Aggregate results are reflected in percentiles.

The principle observations drawn from the evaluation of student comments regarding their experiences during the study aboard components of the CHHS course, and feedback regarding the international requirement, are as follows:

- Students generally prefer in depth experiences rather than a large smattering of more superficial opportunities;

- $\quad$ Students especially enjoy hands on experiences, such as building houses, painting schools, planting trees and shrubbery;

- Opportunities to meet the locals, especially children, are highly valued; 
- Students like to balance learning and living, having some relaxing experiences incorporated into the travel time to balance the learning portions;

- Students are fairly flexible with regard to food and lodging and have a high tolerance for surviving with basic amenities, especially in developing countries;

- Learning language skills, cooking techniques, and other practical aspects of travel are especially well received;

- $\quad$ Students prefer host family accommodations to hotels;

- Students want to see "the good, the bad, and the ugly," and do not want to gloss over the challenges faced by people in developing countries;

- Social activities with local people and hosts are quite beneficial and create an appreciation for the local culture and customs;

- $\quad$ Students really like interacting with children and seniors; and

- Students seek back office support for international activities from both academic and student services units on campus.

As examples of activities that have a higher educational payoff and better customer satisfaction, students appreciated the opportunity to work with local families in home building, community clean-up, cooking, and other activities, rather than just being observers. Most importantly, even if their role was secondary, the students wanted to be involved in service learning. Obviously, the educational value of active involvement is greater than having an observational exposure. Table 1 presents student evaluation data from a typical HHS 350 trip.

Table 1. Illustrative student evaluations/preferences of experience segments, Costa Rica, March 2010

\begin{tabular}{|c|c|c|}
\hline Activity & $\begin{array}{l}\text { Percent Rated } 4 \text { (very good) } \\
\text { or } 5 \text { (excellent) }\end{array}$ & $\begin{array}{l}\text { Percent Rated } 1 \text { (not at all), } 2 \\
\text { (okay), or } 3 \text { (good) }\end{array}$ \\
\hline Ziplining & $95 \%$ & $5 \%$ \\
\hline $\begin{array}{ll}\text { Host } & \text { Family } \\
\text { Accommodations } & \end{array}$ & $91 \%$ & $9 \%$ \\
\hline Senior Home Tour & $83 \%$ & $17 \%$ \\
\hline Wood Factory & $82 \%$ & $18 \%$ \\
\hline $\begin{array}{l}\text { Volunteer at Children's } \\
\text { Home }\end{array}$ & $81 \%$ & $19 \%$ \\
\hline Hospital Tour & $78 \%$ & $22 \%$ \\
\hline Health System Lecture & $74 \%$ & $26 \%$ \\
\hline Language Classes Lectures & $73 \%$ & $27 \%$ \\
\hline Education System Lecture & $73 \%$ & $27 \%$ \\
\hline City Tour & $68 \%$ & $32 \%$ \\
\hline Clinic Tour & $65 \%$ & $35 \%$ \\
\hline Cooking Lesson & $65 \%$ & $35 \%$ \\
\hline Island Cruise & $65 \%$ & $35 \%$ \\
\hline Medicinal Plant Lecture & $59 \%$ & $41 \%$ \\
\hline
\end{tabular}

Note: $\mathrm{n}=20$

\subsection{Added Value: Service Learning}

Now in production mode, the college has been adding new service learning activities to HHS 350 based on the findings that this appears to be a "sweet spot" in the international experience. Several researchers have 
documented the benefits of service learning (Astin, et al., 2000; Bringle \& Hatcher, 1996; Howard, 2003; Jacoby, 1996; Saltmarsh, 2005; Saltmarsh \& Zlotkowski, 2011). Astin, et al. (2000) identified effects on student development in cognitive and affective areas such as academic performance, values, self - efficacy, leadership, choice of service career, and plans to participate in service learning after graduation. Critical factors that are linked with service learning include students' degree of interest in the subject and the professor's facilitation of course discussions.

\subsection{Design Considerations}

The principle considerations in designing HHS 350, reviewed in Table 2, reflect the practical and philosophical parameters driving the international requirement itself. Designing an experience that would provide service learning, cultural exposure, and critical thinking about global issues were primary educational considerations. Given that CHHS students generally pursue careers that feature clinical work, the course designers incorporated activities that are applicable to future roles in clinical environments. Integrating HHS 350 and establishing relevance to all of the CHHS disciplines was another consideration. A less obvious, but critical concern, was identifying instructors willing to travel to the various countries associated with the HHS 350 course. A key feature of HHS 350 is that instructors accompany student groups to each travel location to provide oversight and facilitate discussions. During the current era of retrenchment in higher education, it is challenging to identify both didactic classroom and field travel instructors.

\subsubsection{Institutional Considerations}

Institutional considerations include state funded versus self-support financing, ensuring stakeholder buy-in, tracking and evaluating outcomes, coordination with student services such as financial aid, health services, academic advising and maintaining a proactive stance regarding risk management issues. The university provides academic programs primarily through state supported funding. However, certain programs can be offered through self-supported funding, a mechanism operated by the university's College of Extended Studies and which is totally funded from student fees, rather than from any state general fund support. Many of the programs, including international opportunities, utilize this avenue, which offers some advantages in added administrative and fiscal flexibility.

Securing support from various stakeholders, such as faculty, students, and administrators was a critical concern. This involved regular meetings with school directors, key faculty members, and student affairs staff to obtain feedback and solicit support. Students were contacted about the international mandate at various junctures: new student orientation, via advising sessions with the college's international coordinator, informational sessions, mass email correspondence, and web site updates.

\subsubsection{Tracking and Evaluation}

The college implemented a tracking and evaluation system to provide feedback for decision making. Every student who is required to meet the international travel mandate is entered into a database. All students, including those enrolled in HHS 350, complete pre and post travel surveys, and this data is used to inform the classroom and travel portions of all courses and to assess the requirement.

\subsubsection{Risk Management}

Risk management is a particular concern in international travel. Pre-travel preparation of students for the contingencies of such travel is essential. Emergency preparations for the range of unexpected events that occur in travel are important in preparing the instructor for supervisory responsibilities. Attention to the travel environment and other preventive considerations are also critical. For example, the university generally excludes undergraduate travel to countries with US State Department Travel Warnings; immunizations based on the United States Center for Disease Control recommendations are suggested for all travel.

\subsubsection{Practical Considerations}

Finally, practical considerations include student financial support such as scholarships and loans, program availability, and selection of appropriate travel locations. The university student fee supported Associated Students' Study Abroad Scholarship mentioned previously is available via application process. This scholarship program is used extensively by CHHS students as award priority is given to applicants with an international travel requirement. Competition for funds has intensified as more students pursue study abroad. The CHHS Dean's Office also has a travel scholarship, however funds are quite limited. This funding need has been added to the college's development agenda. To meet capacity, the course designers have been adding new travel locations and expanding others when appropriate. Selecting suitable travel locations based on State Department risk reports is another consideration. 
Table 2. Principle considerations in designing the international requirement

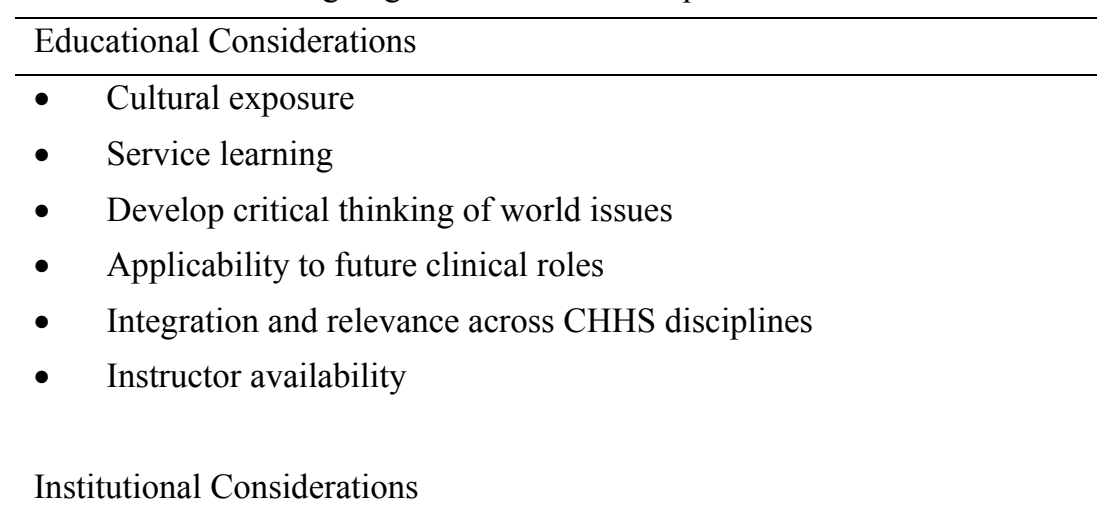

- $\quad$ State General Fund support

- $\quad$ Self-support (student fee-based)

- Stakeholder buy-in (faculty, students, and administrators)

- Student services coordination

- Tracking and evaluation to provide feedback for decision making

- $\quad$ Risk management - pre-travel and emergency precautions

Practical Considerations

- Financial support

- Scholarships and loans

- Program availability to meet capacity

- $\quad$ Selection of appropriate travel locations

\section{Personal and Professional Development}

An international experience meets specific individual student personal development objectives, academic educational objectives, and institutional goals in higher education. These are depicted in Table 3 . The key attributes were developed from the learning outcomes for the course which are based on literature review findings. The attributes depicted mirror the documented effects of student participation in service learning abroad (Boyle, et al., 1999; Bringle, et al., 2011; Dyjack, et al., 2001; and Evanson \& Zust, 2004). Students involved in HHS 350 reported gains in the following areas: cultural awareness; knowledge about health and human services delivery abroad; global understanding; some increase in second language fluency; and enhanced clarity regarding career path. The host family homestay experience enriched cultural learning and facilitated student involvement. The leader-facilitated group discussions and reflections reinforced student learning outcomes. 
Table 3. Attributes of international experience

\begin{tabular}{|c|c|c|c|}
\hline & Congruence With: & & \\
\hline Attribute & $\begin{array}{l}\text { Student Personal } \\
\text { Development }\end{array}$ & Academic Agenda & Institutional Goals \\
\hline $\begin{array}{l}\text { Cultural } \\
\text { Awareness/Diversity }\end{array}$ & $\begin{array}{l}\text { Exposure for most } \\
\text { students }\end{array}$ & $\begin{array}{l}\text { Experience diverse } \\
\text { cultures }\end{array}$ & $\begin{array}{l}\text { Meet university goal } \\
\text { for cultural diversity } \\
\text { (upper division } \\
\text { course) }\end{array}$ \\
\hline $\begin{array}{l}\text { Learn about Health \& } \\
\text { Human Services Delivery } \\
\text { Abroad }\end{array}$ & $\begin{array}{l}\text { Knowledge regarding } \\
\text { health \& human services } \\
\text { in developing countries }\end{array}$ & $\begin{array}{l}\text { Understand the delivery } \\
\text { of health \& human } \\
\text { services abroad }\end{array}$ & $\begin{array}{l}\text { Attain an } \\
\text { interdisciplinary view } \\
\text { of globalization }\end{array}$ \\
\hline Build Resume & $\begin{array}{l}\text { Future career } \\
\text { enhancement and pursuit } \\
\text { of service activities }\end{array}$ & $\begin{array}{l}\text { Experience diverse } \\
\text { cultures and global social } \\
\text { justice issues }\end{array}$ & $\begin{array}{l}\text { Prepare students for } \\
\text { success in a global } \\
\text { society }\end{array}$ \\
\hline Global Understanding & $\begin{array}{l}\text { Knowledge of key global } \\
\text { health \& human services } \\
\text { and social justice issues }\end{array}$ & $\begin{array}{l}\text { Understand global } \\
\text { concerns such as poverty, } \\
\text { safe water, food security, } \\
\text { etc. }\end{array}$ & $\begin{array}{l}\text { Promote cross cultural } \\
\text { sensitivity regarding } \\
\text { critical global issues }\end{array}$ \\
\hline $\begin{array}{l}\text { Fluency in Second } \\
\text { Language }\end{array}$ & $\begin{array}{l}\text { Add to abilities to } \\
\text { understand and speak a } \\
\text { second language }\end{array}$ & $\begin{array}{l}\text { Enhance second language } \\
\text { fluency }\end{array}$ & $\begin{array}{l}\text { Shape interactions and } \\
\text { cultural learning }\end{array}$ \\
\hline
\end{tabular}

The university is committed to providing students with opportunities to extend classroom learning and international education is a priority for CHHS. HHS 350 explores worldwide economic, political, cultural, social and health challenges, and provides students the opportunity to experience and witness these challenges first-hand in an international setting. The course is designed to offer a deeper understanding of the society in which we live and includes topics such as globalization, poverty and population, endemic diseases and surveillance, international health care, global maternal and child health, international social services, and cultural competence and sensitivity.

\subsection{Preliminary Evaluation Data}

Student evaluation data indicates that cultural activities, homestays, and hands-on service learning provide the highest educational payoff. The educational value of direct involvement is far greater than having observational exposure alone. Principle concerns in implementing a college-wide mandate include educational, institutional, and practical considerations such as cultural exposure, integration across disciplines, instructor involvement, funding concerns, financial support, and risk management precautions. Success, by all accounts, is derived from the congruence between three milestones: an academic agenda, student personal goals and an institutional goal of globalization. Figure 1 depicts the synergy that occurs when the milestones are aligned. An academic agenda that satisfies student personal goals and learning objectives is further supported by institutional promotion and the university aim of globalization. 


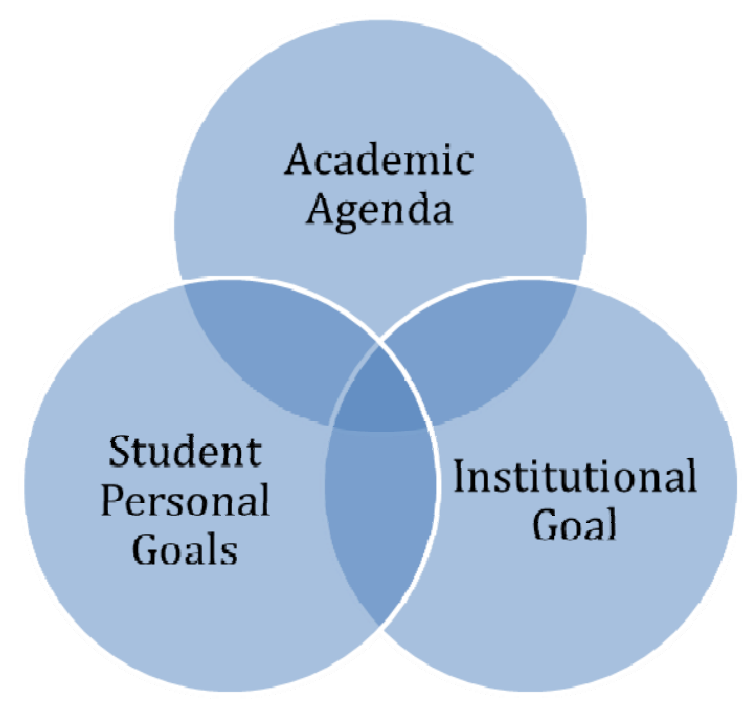

Figure 1. Milestones for success: international mandate

\section{Limitations}

Implementing an international mandate poses limitations due to the nature of the academic requirement and the self-selection process of participants in choosing travel locations. These factors may have influenced the satisfaction that was derived from the activities and the overall perception of the experience. Despite these limitations, students were involved in the course design and planning which helped create a meaningful learning experience. Another limitation is the college context. The CHHS represents the "allied health" professions at the university. The process used to implement the requirement in a college focusing on "health and human services" may need to be adapted to other disciplines. Finally, the university is a very large and diverse public institution in southern California and the CHHS is especially diverse.

\section{Implications}

There are several implications for educational policy. The CHHS mandate underscores the importance of offering short-term study abroad options to students in degree programs with highly structured curriculum and preliminary data from HHS 350 supports the effectiveness of these programs. An international experience associated with a college level course broadens student perspectives and provides personal and professional benefits. This is especially salient since the experience affords students the opportunity to shadow health and human services professionals abroad.

From a policy perspective, university support is required to make an international study mandate successful. The complications involved in implementing a broad-based requirement are vast, ranging from student and faculty safety and security to travel and instruction costs and overall management of the effort. Institutions considering this requirement would benefit from both top-down and bottom-up support to ensure faculty, administrative, and student buy-in. Faculty is a critical stakeholder given that their decisions support curriculum change.

Another implication concerns the congruence between an academic agenda, student goals and the overarching institutional goal. As noted, a successful initiative is based on the congruence between these three critical elements.

Finally, there are implications for future research. Given that this is a relatively new requirement and that it is too early to draw conclusions from the initial database, the CHHS plans to do prospective monitoring, and will conduct further longitudinal analysis.

\section{Conclusions}

The empirical conclusions from assessing and formulating a college-wide international requirement have implications for other large institutions. Top down and broad based institutional support ensures faculty buy-in. Following the support and proper preparation of faculty, the development of agency partnerships abroad is critical. Student engagement is enhanced by the addition of "value-added" activities such as home-building and community work and by including social and cultural events. Finally, pre and post assessment activities enable educators to gauge learning outcomes to improve the curriculum and field work aspects of the experience. 
A mandated international experience for all undergraduate students in the CHHS has been a bold move to expand student horizons and promote university goals. This may be the first time an entire health and human services college in a large public United States university has implemented such a mandate. The complexity of such an effort has been evident from nearly every aspect of the planning and implementation of this requirement, but the rewards, expressed by student feedback, are substantial. A systematic and analytical approach to this initiative permits sharing of valuable experiences with others as the global nature of our world and educational imperatives continue to evolve.

\section{References}

Astin, A. W. (1984). Student Involvement: A developmental theory for higher education. Journal of College Student Personnel, 25, 297-308.

Astin, A., Vogelgesang, L., Ikeda, E., \& Lee, J. (2000). How service learning affects students (Executive Summary). Retrieved

from http://74.125.155.132/scholar?q=cache:asOCTBQDPL0J:scholar.google.com/+How+service+learning+affe cts + students, + Astin, + et.+al., $+2000 \& h l=$ en\&as_sdt=0,5 (June 15, 2011)

Boyle, D., Nackerud, L., \& Kilpatrick, A. (1999). The road less traveled: Cross-cultural, international experiential learning. International Social Work, 42(2), 201-214. http://dx.doi.org/10.1177/002087289904200208

Bringle, R. G., \& Hatcher, J. A. (1996). Implementing service learning in higher education. Journal of Higher Education, 67(2), 221-239. http://dx.doi.org/10.2307/2943981

Bringle, R. G., Hatcher, J. A., \& Jones, S. G. (2011). International service learning: Conceptual frameworks and research. Sterling, Virginia: Stylus.

Chickering, A. W., \& Reisser, L. (1993). Education and Identity (2nd ed.). San Francisco: Jossey-Bass.

Dutschke, D. (2009). Experiential Public Health Study Abroad Education: Strategies for Integrating Theory and Practice. Journal of Studies in International Education, 16(5), $244-254$. http://dx.doi.org/10.1177/102831530153005

Daly, D. M., Baker, S., \& Williams, S. J. (In press). A prescription for global education in health and human services. About Campus.

Dyjack, D., Anderson, B., \& Madrid, A. (2001). Experiential public health study abroad education: Strategies for integrating theory and practice. Journal of Studies in International Education, 5, 244-254.

Edwards, J. (2007). Challenges and opportunities for the internationalization of higher education in the coming decade: Planned and opportunistic initiatives in american institutions. Journal of Studies in International Education, 11(3/4), 373-381. http://dx.doi.org/10.1177/1028315307303920

Evanson, T. A., \& Zust, B. L. (2004). The meaning of participation in an international service experience among baccalaureate nursing students. International Journal of Nursing Education Scholarship, 1(1), 1-14.

Gacel-Avila, J. (2005). The internationalization of higher education: A paradigm for global citizenry. Journal of Studies in International Education, 9, 121-136. http://dx.doi.org/10.1177/1028315304263795

Green, M. F., \& Olson, C. (2003). Internationalizing the campus: A user's guide. Washington, D.C.: American Council on Education.

Howard, J. (2003). Service learning research: Foundational issues. In S. H. Billig \& A. S. Waterman, Studying service learning: Innovations in education research methodology (pp. 1-12). Mahwah, NJ: Lawrence Erlbaum Associates, Inc., Publishers.

Jacoby, B. (1996). Service learning in today's higher education. In B. A. Jacoby, Service learning in higher education: Concepts and practices (pp. 3-25). San Francisco: Jossey-Bass, Inc., Publishers.

King, P. M., \& Baxter Magolda, M. B. (2005). A developmental model of intercultural maturity. Journal of College Student Development, 46(6), 571-592. Boston, MA: Pearson Custom Publishing.

Kolb, D. A. (1984). Experiential learning: Experience as the source of learning and development. Englewood Cliffs, NY: Prentice Hall.

McCabe, L. (2001). Globalization and internationalization: The impact on education abroad programs. Journal of Studies in International Education, 5(2), 138-145. http://dx.doi.org/10.1177/102831530152004

Open Doors Report. (2011). Institute of International Education. Retrieved from 
http://www.iie.org/en/Research-and-Publications/Open-Doors (December 5, 2011)

Saltmarsh, J., \& Zolotski. (2011). Higher education and democracy: essays on service-learning and civic engagement. Philadelphia, PA: Temple University Press. 